\title{
A Systematic Approach to Teaching and Learning Machine Design Course
}

\author{
Vinod Kumar V Meti ${ }^{1}$, A. C. Giriyapur ${ }^{2}$, Siddhalingeshwar I. G. ${ }^{3}$, Pooja Sadalagi ${ }^{4}$ \\ 1,2Automation \& Robotics Department, \\ ${ }^{3,4}$ Automobile Engineering \\ B.V. Bhoomaraddi College of Engg \& Tech., Hubli, \\ Karnataka, India \\ ${ }^{1}$ vinod123meti@gmail.com
}

\begin{abstract}
In this modern world students are looking at new method of learning the courses and as well it is very difficult for the instructors/teachers to take attention of students to teach the theory courses. This paper brings a different method of teaching and learning methodology for the machine design course. In this, the tutorial and course project has been linked to the course to develop student's involvement, complex thinking, team management skills, and higher order thinking skills. Here the author would like to share some of the new techniques extracted from the outcome based learning and project based learning approaches to make students and teachers to involve in to the course. Student's feedback and the project did show their involvement in the course.
\end{abstract}

Keywords: Techniques, project, tutorial, learning, involvement.

\section{Vinod Kumar V Meti ${ }^{1}$}

Automation \& Robotics Department,

B.V. Bhoomaraddi College of Engg \& Tech., Hubli, Karnataka, India.

${ }^{1}$ vinod123meti@gmail.com

\section{Introduction}

In this modern world students are moving away from the class room teaching and looking at modern teaching technique. Students are showing more interest on project based learning (PBL) as compared to theory or class room based technique. Students are moving beyond the traditional approach, due to this there is a challenge for the teachers and institutions to adopt new techniques or approaches to attract and involve students towards the course. That's the reason OBE learning approach emerges with new technique to attract and involve students as well as teachers in to the course more effectively.

The aim of all teaching activity is to facilitate and support student learning. Doing this in the best possible way is to show teaching skill. Outcome based education emerges with new learning approach and methodology to reform and renew the traditional learning approaches worldwide. OBE approach has gained prominence recognition in the modern world relate to the engineering educational approaches (Oriah Akir et al., 2012).

OBE support for student learning can take many different forms. Some support activities can be directly perceived by the students. Other activities are less apparent, but still important since they help create good working conditions for teachers and students and thereby have an influence on student learning.

OBE approach is a technique or methodology that guides the educational process toward acquisition of the knowledge, skills, and attitudes needed for effective professional practice in their education. Increasingly adopted by many engineering institutions and also some other educational organizations, the OBE technique involves establishing competency goals, developing curricula, attracting students towards the course, improving complex and higher order thinking skills and other experiences designed to help students reach these goals, 
integrating instruction in the full range of competencies throughout the educational sequence, guiding and evaluating student learning through ongoing assessment of competence, and revising courses and activities in light of student competence outcomes (Robert L et al., 2013).

Project Based Learning (PBL), a teaching and learning model that uses projects to engage students and focus their learning. Projects are complex tasks that involve students in design, problem-solving, decision-making, and investigative activities. Students work autonomously over extended periods of time, and prepare realistic products or presentations (Arends, 1997; Diehl, Grobe, Lopez \& Cabral, 1999; Thomas, 1998).

For teachers who use PBL, the task of classroom management is quite different from that faced by teachers employing the traditional instructional methods of lecture, discussion, and seatwork. With PBL, very little time is devoted to teacher-directed seatwork or whole-class discussions. Students spend the majority of their time working on their own or in small groups. Teachers typically do not lead instructional activities, nor do they dispense resources, or present material to be learned. Students find their own sources, conduct their own research, and secure their own feedback. Experienced PBL teachers report that they spend very little time promoting student engagement or handling student misbehavior. Teachers often spend their time participating in projects as peers rather than as classroom managers.

Through the PBL approach, students take leadership for their learning, structure and organize an action project and start communicating, thinking and involving in to the project. In other words, students become empowered and educated about new technology developed in the $21^{\text {st }}$ century (Erica Baker et al., 2011).

In this paper the author would like share some of the new techniques extracted from the $\mathrm{OBL}$ and $\mathrm{PBL}$ approaches to make students and teachers to involve in to the course. Here the author explains the course with the help of tutorials which is linked to the course. By giving design task as a course project for a batch of students and involving them in to the course through course project. Through these approaches student's involvement and feedback shows that complex thinking, higher order thinking, communication skills, and team management skills has been developed.

\section{Literature Review}

Project based learning approach moving beyond generating student interest. Well-designed projects encourage and attract students/people as well improves higher order thinking (Thomas, 1998). Brain research enumerates the value of these learning activities carried out during the research/project.

Students encourage and attracted when they are connected to problem solving activities or project based activities. Students are enhanced and helped to understand facts and skills relevant to the activities (Bransford, Brown, \& Cocking, 2000, p. 23).

PBL offers a wide range of benefits to both students and teachers/instructors. Institutions in the modern world encourage project based learning approaches in institutions to engage, attract, motivate and encourage students learning skills and also improve institutional academic performance (George Lucas Educational Foundation, 2001).

Benefits of PBL for students are as follows:

$\checkmark$ Improved attitude and motivation toward the learning (Thomas, 2000).

$\checkmark$ Institutional academic gains better than the traditional methods and project based learning takes greater responsibility to move beyond the traditional learning approaches (Boaler, 1999; SRI, 2000).

$\checkmark$ Opportunities to develop complex thinking skills, such as higher order thinking skill, problem-solving, team management skill and communication skills (SRI, 2000).

$\checkmark$ Opportunity to develop active learning classroom and encourage students to engage in the activities more effectively (Railsback, 2002).

PBL approach also benefits teachers to enhance their professionalism and collaboration among colleagues, and creates opportunities/platform to build relationships with students (Thomas, 2000). Additionally, many teachers are pleased to find new methodology to encourage, attract and involve students towards the course. PBL approach help students and instructors to benefit more about learning aspects and helps them to move beyond the traditional learning approaches (SRI, 2000).

Accordingly this, article covers research and researchrelated articles on "out-come based education learning," and "project-based learning," that conform to the criteria above.

Outcome-based education (sometimes called Performance-based Education, formerly called Mastery Learning) is a model of education that favors making students demonstrate that they know and are able to do whatever the required outcomes are. The outcomes are specified in terms of individual student learning. The approaches/model rejects the traditional educational inputs and content and time allocation. Instead, OBE focuses on desired outputs. OBE emphasizes setting clear standards for observable, measurable outcomes through which student performance can be empirically measured (Gladie Lui et al.,).

Educational process which is based on trying to achieve certain specified outcomes in terms of individual student learning. Thus, having decided what are the key advantages students should understand and be able to do or the qualities they should develop, both structures and curriculum are designed to achieve those capabilities or qualities. Educational structures and curriculum are regarded as means not ends (Faizah Abd Majid). 
An outcome based learning approach; it is what the student should be able to do at the end of a course. OBE is an approach to education in which decisions about the curriculum are driven by the exit learning outcomes that the students should display at the end of the course. Outcomes based learning approach where teaching and learning activities are developed to support the learning outcomes and helped to design and develop the assessment towards the course (Margery H Davis, 2003).

\section{Objectives}

The Primary Objective is

$\checkmark$ To motivate, encourage and engage students and also build knowledge towards the course more effectively.

\section{Specific Objectives are}

$\checkmark$ Effectively make utilize of facility available in the department or institution.

$\checkmark \quad$ To motivate students to develop inter personal skills, communication skills and team management skills in the context of course project work.

$\checkmark \quad$ To enhance the higher order thinking skills.

$\checkmark$ To motivate students to support and guide their teammates.

$\checkmark \quad$ To explore present world skills or knowledge to the students.

\section{Methodology}

At the beginning of this course students should have knowledge about other courses (pre-requisites) which help them to involve in to the course more effectively. Students in this department where they are going learn multidisciplinary subjects, but still the students need to undergo the knowledge of present world skill. In this course students learn how to design the machine components/parts as described by the course instructor in regular theory classes but practically students cannot come across market survey, need, material selection, processes and marketing which is shown in figure 1 , because of time and curricular design constraints.

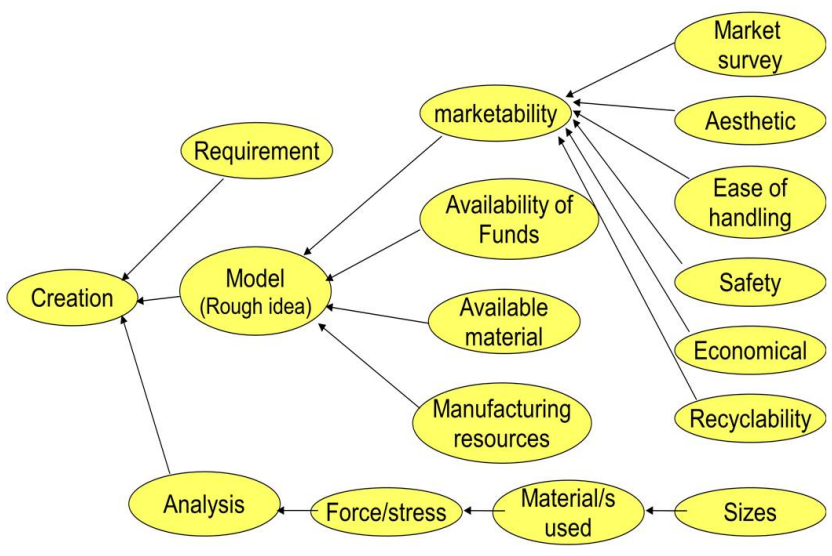

Fig. 1. Design process for the students to follow for their course project.

Here it is very easy for the students to attract towards the course because they are already having knowledge of some other courses (pre-requisites) which is really necessary for this course. Through literature survey some courses are figured to motivate and involve students in to this course. Figure 2 shows the prerequisites for this course to motivate and involve students in to course.

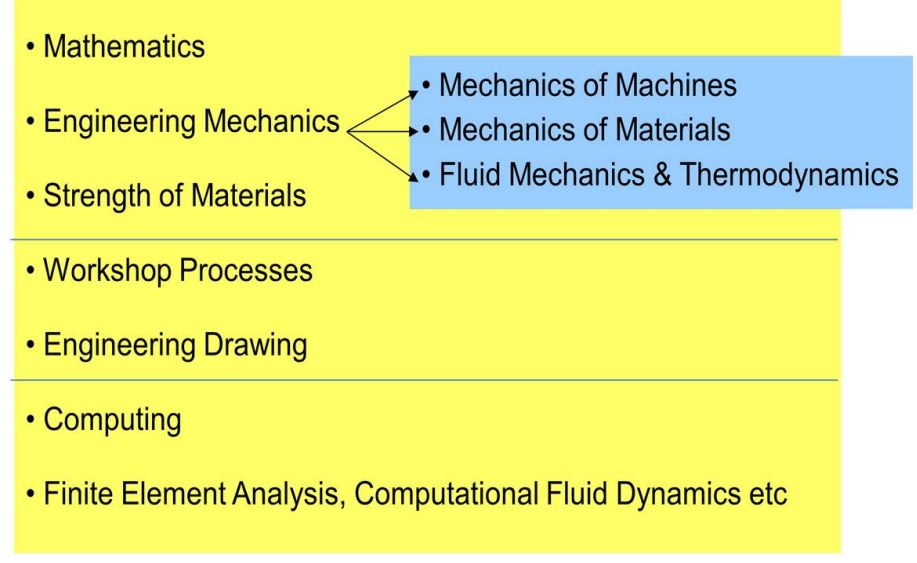

Fig. 2. Prerequisites for this course to motivate and involve students in to course.

In this course, the course instructor has designed the course in to two categories, theory and tutorials. In the regular theory classes students undergo design concepts and techniques to design the machine components or parts. In tutorials students has to carryout course project by following design processes taught in the theory classes. Here the course instructor allotted credits for the tutorials to effectively carryout the course projects/tutorial.

In this course, the instructor formed teams; in each team max 5 students are working for the course project. Each team has to follow the simple design process as explained in the course and has to select one machine/machine component to design by doing survey. At 
the end of the course the students has to submit the report along with the course project model. Marks/credits were allotted to each team according to their performance carried out throughout the course.

\section{Result and Discussion}

To design and develop courses and also attract students towards the course at this modern engineering world is challenging task. Everyday there is a new challenge for the instructor to attract students towards the course. In this challenging world, further improvement and development of the course is necessary. To keep these things in mind, the instructor collected student's feedback. Students have responded positively towards the design and development of the course. The table 1 shows the feedback received from the students.
Table 1. Feedback obtained from students for the questions raised towards the course.

\begin{tabular}{|l|c|c|c|c|}
\hline \multicolumn{1}{|c|}{ Questions } & Excellent & Good & $\begin{array}{c}\text { Satisfa } \\
\text { ctory }\end{array}$ & $\begin{array}{c}\text { Not } \\
\text { Satisfa } \\
\text { ctory }\end{array}$ \\
\hline $\begin{array}{l}\text { 1. Design of the } \\
\text { course. }\end{array}$ & 20 & 15 & 0 & 0 \\
\hline $\begin{array}{l}\text { 2. Involvement/interest } \\
\text { lengagement with } \\
\text { the course. }\end{array}$ & 27 & 8 & 0 & 0 \\
\hline \begin{tabular}{l} 
3. Time Management. \\
\hline $\begin{array}{l}\text { 4. Assessment of the } \\
\text { course. }\end{array}$
\end{tabular} & 7 & 18 & 9 & 1 \\
\hline $\begin{array}{l}\text { 5. Help you in your } \\
\text { academic or } \\
\text { professional career. }\end{array}$ & 24 & 9 & 2 & 0 \\
\hline $\begin{array}{l}\text { 6. Help you to improve } \\
\text { your project } \\
\text { management skills, } \\
\text { communication } \\
\text { skills, Complex } \\
\text { thinking, higher } \\
\text { order thinking and } \\
\text { Present world skills. }\end{array}$ & 29 & 6 & 0 & 0 \\
\hline
\end{tabular}

Figure 3 shows the graph generated from the students feedback. With this graph we can conclude that student's response towards the design and development of the course was very good. With this methodology students are able to attract and motivate towards the course more effectively. This activity/methodology helps students to improve their project management skills, communication skills, complex thinking skills, higher order thinking skills and present world skills. But student's feedback also says further improvement is required to implement this course more effectively.

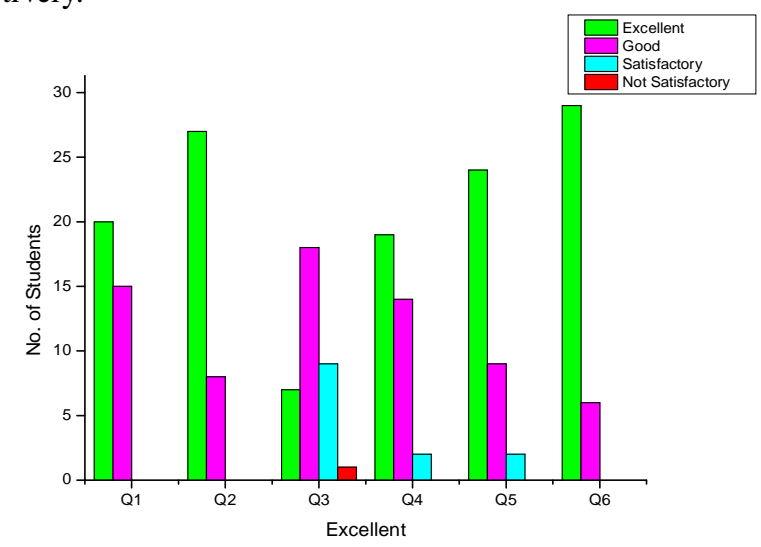

Fig. 3. Students feedback.

To ensure design and development or the activity/methodology adopted in this course are shown with the help of the course projects handled by each of the team. Each team successfully designed the machine or machine components using the facility available in the department (Solid Works-Modeling \& Simulation Software). Figure 4, shows student's performance in the course project. These samples of course project enumerate the development of student's complex and higher order thinking skills.

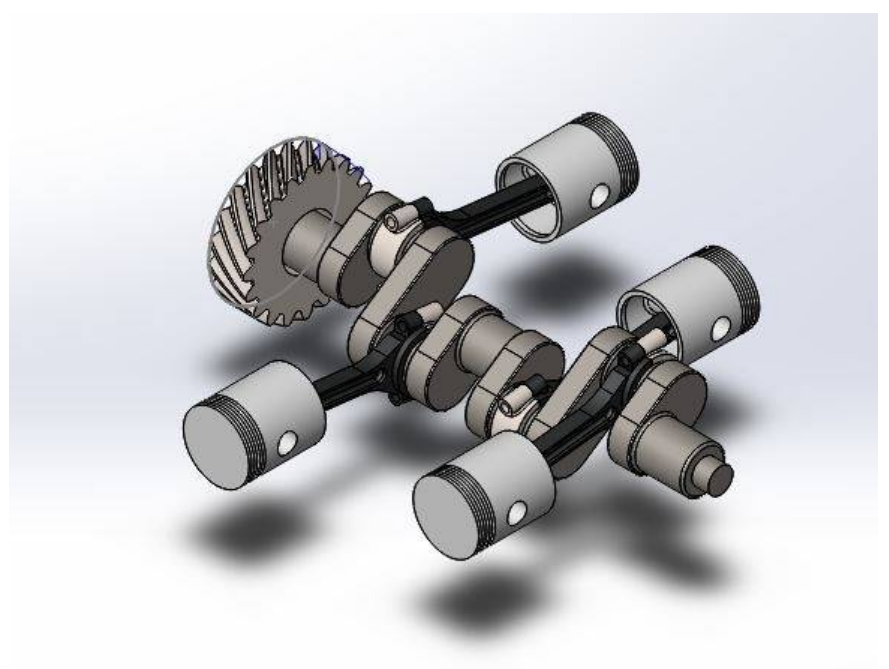

(a) 


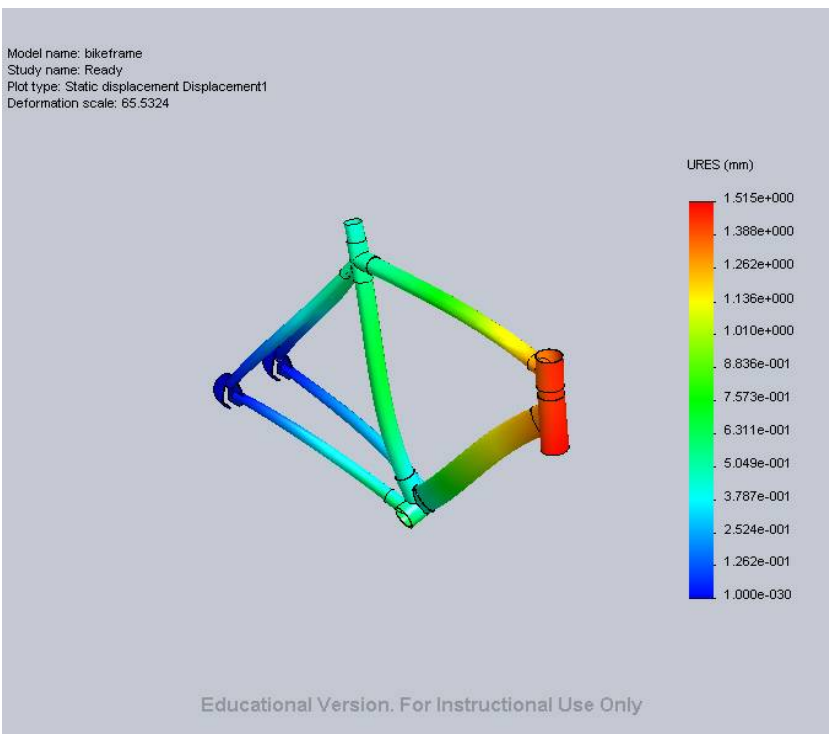

(b)

\begin{tabular}{|c|c|c|c|}
\hline \multirow[t]{2}{*}{ Model Reference } & \multicolumn{2}{|c|}{ Properties } & Components \\
\hline & $\begin{array}{r}\text { Name: } \\
\text { Model type: } \\
\text { Default failure } \\
\text { criterion: } \\
\text { Yield strength: } \\
\text { Tensile strength: } \\
\text { Elastic modulus: } \\
\text { Poisson's ratio: } \\
\text { Mass density: } \\
\text { Shear modulus: } \\
\text { Thermal expansion } \\
\text { coefficient: }\end{array}$ & $\begin{array}{l}\text { Alloy Steel } \\
\text { Linear Elastic Isotropic } \\
\text { Unknown } \\
6.20422 \mathrm{e}+008 \mathrm{~N} / \mathrm{m}^{\wedge} 2 \\
7.23826 \mathrm{e}+008 \mathrm{~N} / \mathrm{m}^{\wedge} 2 \\
2.1 \mathrm{e}+011 \mathrm{~N} / \mathrm{m}^{\wedge} 2 \\
0.28 \\
7700 \mathrm{~kg} / \mathrm{m}^{\wedge} 3 \\
7.9 \mathrm{e}+010 \mathrm{~N} / \mathrm{m}^{\wedge} 2 \\
1.3 \mathrm{e}-005 / \mathrm{Kelvin}\end{array}$ & $\begin{array}{l}\text { SolidBody } 1 \text { (Boss- } \\
\text { Extrude1)(connector1) }\end{array}$ \\
\hline
\end{tabular}

(c)

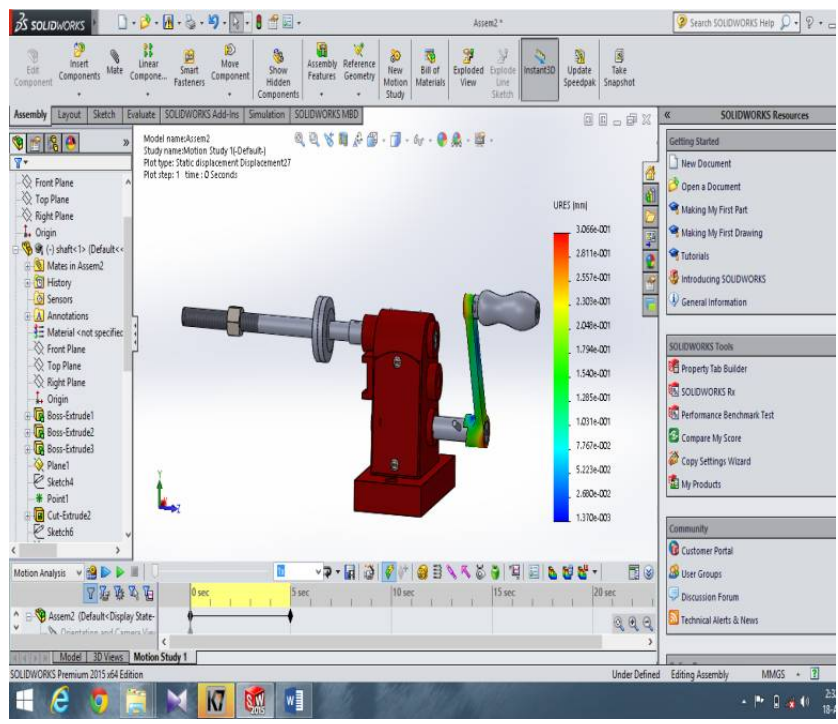

(d)

Fig. 4. Samples of students course project carried out during the course: (a) Crankshaft Mechanism (b) Bicycle Frame (c) Material Properties (d) Mechanical Grinder.

\section{Conclusion}

Good response given by the students towards the design and development of the course. Student's feedback helps instructor to develop such kind of activities in courses to encourage and develop knowledge towards the course.

Outcome based learning and Project based learning helps instructor/institution to design and develop the course as well as these gives new methodology to improve the course, encourage and motivate students towards the course and encourage them to move towards the modern engineering world.

In this we can conclude that students are more attractive towards the course and helps to improve their personal skills, communication skills and team management skills in the context of course project work. This also supports students to enhance higher order thinking and complex thinking skills.

\section{Acknowledgement}

The authors would like to acknowledge the Vice Chancellor, Registrar, KLE Technological University, the Principal, B.V.Bhoomaraddi College of engineering \& Technology, Hubli for giving this opportunity to design and develop the curriculum. The author also would like to acknowledge supporting staff members for their support throughout the completion of course successfully.

\section{References}

Oriah Akir, Tang Howe Eng, Senian Malie (2012), "Teaching and learning enhancement through outcomebased education structure and technology e-learning support”, 1877-0428 (C) 2012 Published by Elsevier Ltd, Procedia - Social and Behavioral Sciences 62, 87 - 92.

Robert L. Hatcher et al., "Competency-Based Education for Professional Psychology: Moving From Concept to Practice", Training and Education in Professional Psychology, 2013, Vol. 7, No. 4, 225-234.

Arends (1997), "Classroom instruction and management", New York: McGraw Hill.

Diehl, W., Grobe, T., Lopez, H., \& Cabral, C. (1999), "Project-based learning: A strategy for teaching and learning", Boston: Center for Youth Development and Education, Corporation for Business, Work, and Learning.

Thomas, J. W. (1998), "An Overview of Project-based Learning”, Novato, CA: Buck Institute for Education.

Erica Baker et al., "Project-based Learning Model Relevant Learning for the 21st Century", CPacific Education Institute, 2011.

Thomas, J.W. (1998), "Project-based learning: Overview", Novato, CA: Buck Institute for Education. 
Bransford, J., Brown, A., \& Cocking, R. (2000), "How people learn: Brain, mind, experience, and school", Washington, DC: National Academy Press.

George Lucas Educational Foundation. (2001, November 1), "Project-based learning research", Edutopia. www.edutopia.org.

Thomas, J.W. (2000), "A review of research on projectbased learning", San Rafael, CA: Autodesk. http://www.k12reform.org/foundation/pbl/research.

Boaler, J. (1999, March 31), "Mathematics for the moment, or the millennium? Education Week".

SRI International. (2000, January), "Silicon valley challenge 2000: Year 4 Report", San Jose, CA: Joint Venture, Silicon Valley Network. http://pblmm.k12.ca.us/sri/Reports.htm.

Railsback, J. (2002), "Project-based instruction: Creating excitement for learning", Portland, OR: Northwest Regional Educational Laboratory. http://www.nwrel.org/request/2002aug/index.html.

Gladie Lui, Connie Shum, "Outcome-based education and student learning in managerial accounting in Hong Kong," Journal of Case Studies in Accreditation and Assessment, Outcome-based education.

Faizah Abd Majid, "The Use of Reflective Journals in Outcome-Based Education During the Teaching Practicum," Malaysian Journal Of ELT Research, Volume 4, ISSN: 1511-8002.

Margery H Davis, "Educational Strategies: Outcome Based Education," JVME 30 (3) 2003 AAVMC. 